\title{
Juvenile Myasthenia Gravis: A Short Review
}

\author{
Shubhankar Mishra* \\ Department of Neurology, India \\ Received: 阱 November 26, 2018; Published: 制 November 29, 2018 \\ *Corresponding author: Shubhankar Mishra, Department of Neurology, India
}

\begin{abstract}
Juvenile myasthenia gravis (JMG) is an autoimmune disorder of neuromuscular transmission caused by production of antibodies against components of the postsynaptic membrane of the neuromuscular junction. The patients present with a wide range of symptoms-from isolated intermittent ocular symptoms to general muscle weakness with or without respiratory insufficiency. Prepubertal children in particular have a higher prevalence of isolated ocular symptoms, lower frequency of acetylcholine receptor antibodies, and a higher probability of achieving remission. It must be differentiated from congenital myasthenia which is a channelopathy rather than autoimmune disease. Treatment commonly includes anticholinesterases, corticosteroids with or without steroid-sparing agents, and newer immune modulating agents. Plasma exchange and intravenous immunoglobulin (IVIG) are effective in preparation for surgery and in treatment of myasthenic crisis.
\end{abstract}

Keywords: Myasthenia; Ptosis; Pyridostigmine

Abbreviations: JMG: Juvenile Myasthenia Gravis; IVIG: Intravenous Immunoglobulin; MG: Myasthenia Gravis; Ab: Antibodies; AChR: Acetylcholine Receptor; MuSK: Muscle-Specific Kinase; LRP4: Leucine Rich Protein 4; RNS: Repetitive Stimulation Test; SFEMG: Single Fiber Electromyography; CT: Computed Tomography; MRI: Magnetic Resonance Imaging

\section{Introduction}

The first description of myasthenia gravis (MG) with onset in childhood originates from Erb in 1879 [1]. The definition of juvenile myasthenia gravis (JMG) includes infants, children, and adolescents aged 0 to 19 years [2]. JMG patients are subdivided according to the occurrence of the first symptoms as prepubertal (first symptoms before the age of 12 years) and postpubertal (first symptoms after the age of 12 years) [3]. The main action of disease is production of antibodies ( $\mathrm{Ab}$ ) against the components of postsynaptic membrane, predominantly the binding acetylcholine receptor (AChR). MG is divided into five groups: ocular myasthenia (grade I), mild (grade IIa), moderate (grade IIb), severe weakness other than ocular (grade III), and very severe weakness defined by intubation with or without mechanical ventilation (grade IV) [4]. It is a rare disorder of the childhood which accounts for less than 10$15 \%$ with an incidence of 1-5 per million per year [2].

In Asian population, up to $50 \%$ of $M G$ patients present with the first symptoms in childhood (age peak between 5 and 10 years); no difference in sex distribution has been observed. In this population, more than $70 \%$ of cases are restricted to ocular symptoms and benign course is common [2,5]. In post-pubertal children, the clinical course is similar to adult-onset MG. The patients frequently present with ocular symptoms at the onset; generalized-muscle weakness develops in up to $80 \%$ in the course of the disease [2].

Pathogenesis: In the majority of cases MG is caused by antibodies to the nicotinic acetylcholine receptor (AChR) which is found in over $80 \%$ adults with generalised disease but only in $55 \%$ of adults with weakness confined to the oculomotor muscles. Patients with AChR antibodies are often referred to as seropositive. AChR antibodies are probably less frequent in prepubertal patients than in adolescent and adult patients [6]. Antibodies to musclespecific kinase (MuSK) and to Leucine rich protein 4 (LRP4) have been reported in some seronegative patients.

Clinical Features: A typical clinical symptom of abnormal neuromuscular transmission is a fatigability that occurs acute or subacute. The first symptoms may develop as early as in the first year of life [7]. Generally, the developmental milestones are normal before disease onset. Clinical presentation depends on the muscle group affected: ocular problems such as ptosis or ophthalmoplegia, 
bulbar muscle weakness, respiratory muscle involvement, and proximal symmetrical muscle weakness. Ocular symptoms are common at onset. The definition of ocular MG is restricted to the ocular symptoms for 2 years without becoming generalized [8]. Ptosis usually aggravates after physical activity. It may be unilateral or bilateral. Children may complain about double vision. Sometimes, children may present having difficulties in climbing stairs because of diplopia. About $50 \%$ of children with ocular symptoms develop systemic or bulbar muscle involvement within 2 years after onset. If bulbar muscles are involved there will be nasal regurgitation. Symptoms depend upon weakness.

When generalized muscle weakness is there, patients have problems to walk a normal distance or to run, have difficulties in climbing stairs or to rise from a squatting position. In many conditions generalized muscle weakness, which presents as painless fatigability of the bulbar and limb musculature, with dysphonia, dysphagia, and proximal limb weakness. Children are at risk of choking or aspiration and are at increased risk of chest infection. Occasionally, impairment of the respiratory muscles necessitates ventilatory support. This is known as "myasthenic crisis". In the physical examination, children may appear normal if examined after rest; repetitive assessment of muscle strength with standardized tests is recommended [9]. Transient neonatal myasthenia is a condition that results from transfer of maternal AChR antibodies across the placenta leading to defects of neuromuscular transmission in the neonate [10]. Not all mothers have detectable AChR antibodies and a few are asymptomatic at the time. Usually the affected baby is normal at birth, subsequently developing signs such as hypotonia, weak cry, poor suck, reduced movements, ptosis and facial weakness, and occasional respiratory insufficiency requiring mechanical ventilation. Short-term treatment with anticholinesterases is usually sufficient.

\section{Diagnosis: (Table 1)}

Table 1: Diagnostic modalities of myasthenia gravis.

\begin{tabular}{|c|c|c|}
\hline Diagnostic Modality [3] & Specific tests & Importance \\
\hline \multirow{2}{*}{ Physiological tests } & Sleep test & $\begin{array}{c}\text { After having the baseline deficit documented (measurements of ptosis, motility disturbance), the } \\
\text { patient rests quietly with eyes closed for } 30 \text { minutes. The measurements are repeated immediately } \\
\text { after the patient "wakes up" and opens his or her eyes. Improvement after rest is highly suggestive of } \\
\text { MG. }\end{array}$ \\
\hline & Ice pack test & $\begin{array}{l}\text { The ice-pack test is often helpful for diagnosing patients, but only if they have ptosis. An ice pack is } \\
\text { placed over lightly closed eyes for } 2 \text { minutes. Improvement of ptosis occurs in most patients with MG }\end{array}$ \\
\hline \multirow{3}{*}{ Serology } & AchR Antibody & $\begin{array}{l}\text { Detection of antibodies to the AChR supports the diagnosis of JMG. Some of seronegative children } \\
\text { who are negative for AChR antibodies will have "low affinity" antibodies to the AChR which were not } \\
\text { detectable using the standard assays }\end{array}$ \\
\hline & Musk Antibody & $\begin{array}{l}\text { Some MG patients without AChR antibodies are found to have antibodies against muscle-specific } \\
\text { kinase (MuSK). MuSK positive MG is rare in children, and these children represent a distinct subgroup } \\
\text { of JMG, with a marked female predominance. MuSK antibodies appear to be associated with more } \\
\text { severe disease with prominent facial and bulbar weakness and frequent respiratory crises [11]. }\end{array}$ \\
\hline & LRP4 Antibody & $\begin{array}{l}\text { Very low number of seronegative JMG patient turn out to be positive for } \\
\qquad \text { Lrp4-Ab [12]. }\end{array}$ \\
\hline \multirow{2}{*}{ Pharmacological } & Edrophonium test & $\begin{array}{l}\text { Tensilon test involves intravenous infusion of edrophonium. The patient is observed, and ideally } \\
\text { a video recorded, looking for a transient improvement in previously documented weakness, for } \\
\text { example, ptosis, dysphonia. }\end{array}$ \\
\hline & Neostigmine test & $\begin{array}{l}\text { This test is particularly useful in patients who may require a longer observation period for accurate } \\
\text { ocular alignment measurements than that allowed by edrophonium. A positive test produces } \\
\text { resolution of signs within } 30-45 \text { minutes. }\end{array}$ \\
\hline \multirow[t]{2}{*}{ Electrophysiology } & RNST & $\begin{array}{c}\text { Repetitive stimulation test (RNS), usually with low frequency of } 3 \mathrm{~Hz} \text {. In case of a pathological } \\
\text { decrement response (decline from the first to the fifth amplitude more than 10\%), the result is very } \\
\text { suggestive of a transmission defect. }\end{array}$ \\
\hline & SF-EMG & $\begin{array}{l}\text { Single fiber electromyography (SFEMG) is more sensitive than RNSs and can provide pathological } \\
\text { results in patients with normal decrement response in RNSs. }\end{array}$ \\
\hline Imaging & & $\begin{array}{l}\text { Before the steroid therapy, both subcutaneous testing and chest X-ray should be performed to exclude } \\
\text { fluent tuberculosis. Computed tomography (CT) or magnetic resonance imaging (MRI) of the chest to } \\
\text { check for thymus hyperplasia or thymoma are needed. }\end{array}$ \\
\hline
\end{tabular}




\section{Treatment: (Table 2)}

Table 2: Treatment modalities.

\begin{tabular}{|c|c|c|c|}
\hline Clinical Subtype & First line Therapy & Additional Therapy & \\
\hline Ocular myasthenia & Pyridostigmine [13] & Short term steroid therapy & $\begin{array}{l}\text {-Initial dosage of pyridostigmine is } 0.5 \text { to } 1 \mathrm{mg} / \mathrm{kg} / \mathrm{d} \text { every } 4 \\
\text { to } 6 \text { hours, a daily increase up to } 5 \text { to } 7 \mathrm{mg} / \mathrm{kg} / \mathrm{d} \text { is possible, } \\
\text { maximal } 300 \mathrm{mg} / \mathrm{d} \text {. } \\
\text {-In older children/adults, the maximum starting dose is } 60 \\
\text { mg } 3 \text { to } 4 \text { times daily and absolute maximum recommended } \\
\text { dose in adults is } 120 \mathrm{mg} \text { every } 3 \text { hours during the daytime }\end{array}$ \\
\hline $\begin{array}{l}\text { Generalized myasthenia } \\
\qquad[13-15]\end{array}$ & $\begin{array}{l}\text { Pyridostigmine } \\
\quad+\text { Steroids }\end{array}$ & $\begin{array}{c}\text { long-term } \\
\text { immunosuppressants } \\
\text { thymectomy Azathioprine } \\
\text { (Usually used in combination } \\
\text { with corticosteroids } \\
\text { Occasionally used } \\
\text { alone) Cyclosporin A } \\
\text { Cyclophosphamide MMF } \\
\text { Rituximab }\end{array}$ & $\begin{array}{l}\text {-Prednisone and prednisolone are the first-line therapy in } \\
\text { children with persisting symptoms. The starting dosage is } 0.5 \\
\text { to } 1 \mathrm{mg} / \mathrm{kg} \text { (maximum } 30 \mathrm{mg} / \mathrm{d} \text { ), with a possible increase up } \\
\text { to } 2 \mathrm{mg} / \mathrm{kg} / \mathrm{d} \text { (maximum } 60-80 \mathrm{mg} / \mathrm{d} \text { ). } \\
\text {-Recommended initial dose of azathioprine is } 0.5 \mathrm{to} 1 \mathrm{mg} / \mathrm{d} \text {; } \\
\text { increase of } 0.5 \mathrm{mg} / \mathrm{kg} / \mathrm{d} \text { every } 4 \text { weeks up to } 2.5 \mathrm{mg} / \mathrm{kg} / \mathrm{d} \\
\text { (maximum } 150-200 \mathrm{mg} / \mathrm{d} \text { ) in two divided doses is possible. }\end{array}$ \\
\hline Myasthenia crisis & $\begin{array}{l}\text { Pyridostigmine } \\
\quad+\text { Steroids } \\
\text { +Plasmapheresis/IVIg }\end{array}$ & $\begin{array}{l}\text { long-term } \\
\text { immunosuppressants } \\
\text { thymectomy }\end{array}$ & $\begin{array}{l}\text { The standard dose of IVIg has been } 2 \mathrm{~g} / \mathrm{kg} \text { administrated over } \\
\text { the period of } 2 \text { to } 5 \text { days, maximum dose } 150 \mathrm{~g} \text {. This regimen } \\
\text { can be repeated every } 4 \text { to } 8 \text { weeks in patients who have } \\
\text { failed to respond to other therapies. }\end{array}$ \\
\hline
\end{tabular}

\section{Conclusion}

JMG is one of the subtypes of MG with very good prognosis and outcome. It has more ocular predominance then adult MG. Diagnosis is done by both serological and electrophysiological tests. Pyridostigmine is the primary modality of management. Early diagnosis and management can save many patients from acute crisis. To some extent, treatment options for adults may be adapted for children, but specific pathophysiology differences must be considered in this population group.

\section{References}

1. Erb W Zur Kasuistik der bulbaeren Lähmungen (1879) Ueber einen neuen, wahrscheinlich bulbaeren Symptomen komplex. Arch Psychiatr Nervenkr 9: 336-350.

2. Evoli A (2010) Acquired myasthenia gravis in childhood. Curr Opin Neurol 23(5): 536-540.

3. Finnis MF, Jayawant S (2011) Juvenile myasthenia gravis: a paediatric perspective. Autoimmune Dis: 404101.

4. Osserman KE, Genkins G (1971) Studies in myasthenia gravis: review of a twenty-year experience in over 1200 patients. Mt Sinai J Med 38(6): 497-537.

5. Chiu HC, Vincent A, Newsom-Davis J, Hsieh KH, Hung T (1987) Myasthenia gravis: population differences in disease expression and acetylcholine receptor antibody titers between Chinese and Caucasians. Neurology 37(12): 1854-1857.

6. Andrews PI, Massey JM, Howard JF, Sanders DB (1994) Race, sex, and puberty influence onset, severity, and outcome in juvenile myasthenia gravis. Neurology 44(7): 1208-1214.
7. Chiang LM, Darras BT, Kang PB (2009) Juvenile myasthenia gravis. Muscle Nerve 39(4): 423-431.

8. Luchanok U, Kaminski HJ (2008) Ocular myasthenia: diagnostic and treatment recommendations and the evidence base. Curr Opin Neurol 21(1): 8-15.

9. Besinger UA, Toyka KV, Hömberg M, Heininger K, Hohlfeld R, et al. (1983) Fateh-Moghadam A. Myasthenia gravis: long-term correlation of binding and bungarotoxin blocking antibodies against acetylcholine receptors with changes in disease severity. Neurology 33(10): 1316-1321.

10. Tellez-Zenteno JF, Hernandez-Ronquillo L, Salinas V, Estanol B, da Silva $O$ (2004) Myasthenia gravis and pregnancy: clinical implications and neonatal outcome. BMC Musculoskeletal Disorders 16(5): 42.

11. Vincent A, Leite MI. (2005) Neuromuscular junction autoimmune disease: muscle specific kinase antibodies and treatments for myasthenia gravis. Current Opinion in Neurology 18(5): 519-525.

12. Pevzner A, Schoser B, Peters K, Cosma NC, Karakatsani A, et al. (2012) Anti-LRP4 autoantibodies in AChR- and MuSK-antibody-negative myasthenia gravis. J Neurol 259(3): 427-435.

13. McMillan HJ, Darras BT, Kang PB (2011) Autoimmune neuromuscular disorders in childhood. Curr Treat Options Neurol 13(6): 590-607.

14. Ionita CM, Acsadi G (2013) Management of juvenile myasthenia gravis. Pediatr Neurol 48(2): 95-104.

15. Ware TL, Ryan MM, Kornberg AJ (2012) Autoimmune myasthenia gravis, immunotherapy and thymectomy in children. Neuromuscul Disord 22(2): 118-121. 
(c) This work is licensed under Creative

To Submit Your Article Click Here: Submit Article

DOI: $10.32474 /$ PAPN.2018.02.000127

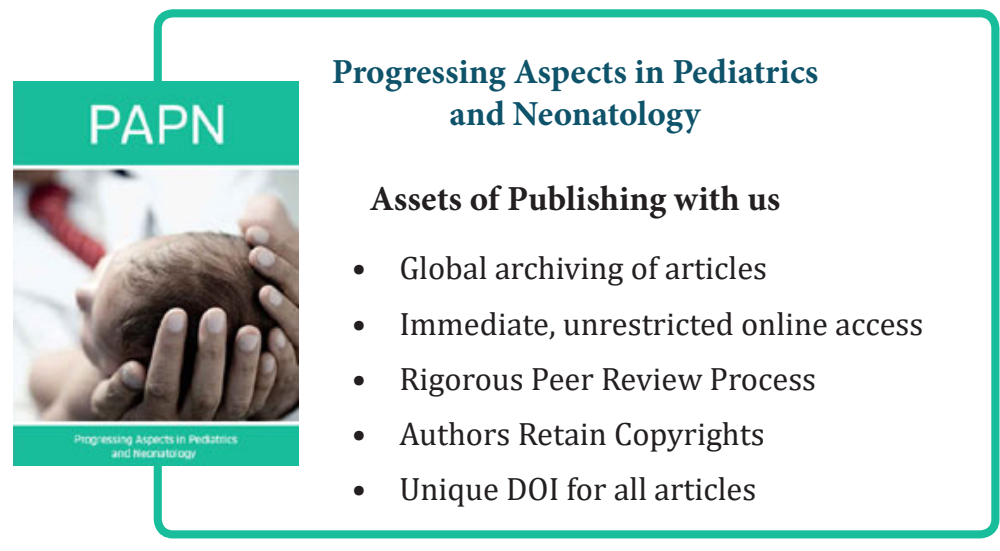

